\title{
Society, space and the public realm: beyond gated individualism
}

\author{
MARY P. CORCORAN \\ National University of Ireland, Maynooth ${ }^{1}$
}

\begin{abstract}
A feature of late modern society is the economisation and privatisation of social life resulting in a decline in the public realm. Judt has observed that we are drifting toward a society of 'gated individuals who do not know how to share public space to common advantage' (2010: 216). Similarly Oldenburg (1989) has expressed concerns about the sustainability of third places - places that occupy the space between the marketplace, workplace and home place - in the modern era. He argues that 'third places' are being replaced by 'non-places' - places where individuals relate to each other purely in utilitarian terms. Non-places promote civil disaffiliation rather than civil integration. This article argues for an exploration of the 'spaces of potential' within the public realm of the city that can help to promote relationships of trust, respect and mutuality. Acknowledging and promoting such 'spaces of potential' amounts to a challenge to the privatisation and economisation of social life. Moreover, it creates the possibility of a reinvigorated public sphere and an enhancement of civil integration.
\end{abstract}

Key words: economisation, privatisation, public realm, space of potential, civil integration

\section{Introduction}

A feature of late modern society has been the economisation and privatisation of social life. This has occurred against a backdrop where the commitment to the public and public goods in general has been severely tested by the fetishisation of the deregulated marketplace. The working out of these processes raises questions about the viability of the concept and practice of 'publicness' in the twenty-first century. In this paper I will argue, however, that the public is more resilient than it is often given credit for. In all sorts of ways, 'publicness' remains salient if frequently latent in our understanding of contemporary society. Before 
embarking on an exploration of the public - its problems and its promise - I would first like to step back and review the wider processes framing current understandings of the self and society. While these processes are discernible in advanced capitalist societies more generally, I will focus here on the Irish case. I will review the process of economisation which I argue has undermined the notion of the social self. Secondly, I will review the pervasive anti-public discourse which has had the effect of weakening the notion of the public self. The paper then goes on to look at the special case of the public realm of the city, and to argue that herein lie multiple and diverse opportunities for a vigorous reanimation of both the social and the public self.

\section{Economisation: erasing the social self}

Modern economics - from the counterpoints of Adam Smith on the one hand and Karl Marx on the other - was 'premised on political economy'. As a discipline it located itself within wider historical, political and sociological contexts. John Kenneth Galbraith's The Great Crash, first published in 1955 and never since out of print, provides a good example of economic analysis that is acutely cognisant of historical, political and sociological contexts.

It is only relatively recently that the discipline has become almost exclusively based on the narrow foundations of the hypothetical 'rational choice subject'. The second-generation Chicago School economists who came to prominence in the 1970s stripped away all of economics' philosophical, political, historical and sociological underpinnings. Instead, they presented a nakedly fundamentalist so-called neo-classical version of economics. The rational choice subject is elaborated in terms of a mathematically based, solipsistic science of modelling and measuring. Complex mathematical models that purport to predict the collective expressions of rational choice action have flourished as the modus operandi of Wall Street since the 1990s. Free market economics appealed to American radical individualism (Palley 2004). 'Economisation' - the hegemony of 'rational choice' theory and mathematical modelling - intensified the processes of financialisation and globalisation. The latter offered a unique context of opportunities for profit making through the mathematical modelling of risk on derivatives traded on a globally dispersed futures market.

Economisation is manifest locally in Ireland in the institutionalisation of Chicago School ideas in the key offices and agencies of the state and its academic advisory bodies. This kind of economic thinking - which is really a historical aberration in the broader history of economics, though it has become hegemonic - imagines itself 'objective', 'value free', 'rational' and so on. Essentially, it constitutes an ideology founded in Milton Friedman's avowed counter-Marxist anti-communism. The Chicago School principles elucidated by Alan Greenspan and his counterparts eschewed broader philosophical contexts and subtleties 
and were mechanically and dogmatically put into practice, in Ireland as much as in the USA.

\section{The lure of money}

More than one hundred years ago, Georg Simmel in The Philosophy of Money recognised that the money economy - the model of modernity - has a particularly corrosive power in terms of its reach into hitherto non-monetary realms of the social system. He warned that the utilitarian ethos and calculative frame of mind that it promoted were ultimately subversive of individual and group identities. For Simmel, a key aspect of the modernist project was the individual's attempt to keep the objective culture produced by the money economy at bay, and to develop, through myriad forms of belonging, a subjective identity.

It was, above all else, the money economy that came to define Irish society in the years leading up to the 2008 crash, as more and more spheres of social life became subject to a utilitarian ethos. An economistic perspective promotes the economic self over the social or reflexive self, and privileges private economic interest at the expense of the collective good. A key challenge for devising democratic renewal today - in the face of financial meltdown and widespread political de-legitimation - is finding a way to overcome the pervasive economisation of everyday life and restoring a values-based form of subjectivity.

Sociological understandings of reality tend to be more nuanced that those of economists, because social reality is itself not clear-cut, but messy and complex. It has, however, been the economist and not the sociologist who has been the preferred expert or talisman on Ireland's recent rise and fall. The economist speaks for and to the financial self. As Judt observes: 'for the last 30 years when asking ourselves whether we support a policy, a proposal or an initiative, we have restricted ourselves to issues of profit and loss - economic questions in the narrowest sense' (2010: 34). Politics, policy and popular discourse in Ireland from the turn of the twenty-first century was suffused with matters pertaining to money and finance. It was as if the country had become coterminous with the economy, squeezing out the notion of the social self. The emergence of the David McWilliams phenomenon is an instructive case in point. David McWilliams spent ten years working as an economist and banker before launching himself in 2000 as a TV and radio broadcaster. In 2006, McWilliams published The Pope's Children, the first of a trilogy of books that provided an entertaining guide to the consumer excesses associated with the Celtic Tiger era. Although an economist by training, McWilliams' books fall into the category of sociology-lite; lots of appealing typologies and anecdotes with scant reference to systematic evidence. Nevertheless, his ubiquity across a range of media platforms and his knack for coining memorable phrases meant that 'McWilliamonics' has become a prime lens through which to interpret Irish society. The economic collapse in 2008 
arguably intensified the economisation of public discourse. For several years debate raged as to whether or not the country's fundamentals were sound (they weren't), whether or not there would be a soft landing in the property market (there wasn't) and whether or not the bank bailout would solve liquidity problems (it didn't). In December 2010 staff from the International Monetary Fund (IMF) visited Dublin to meet with government officials and work out a bailout plan. An iconic photograph of Ajai Chopra, head of the IMF's mission to Ireland walking past a homeless man begging in a Dublin street became a leitmotif for all that had gone wrong with the Irish economy. After two years of financial firefighting, speculation and denial, the government admitted that it could not alone solve the problems generated by the crisis. Under the terms of the bailout plan, to which the government acceded, spending must be cut by $€ 12.4$ billion by 2015 . The sovereignty of the Irish state was diluted in the interest of paying off private bond holders, representing a low point in the history of the Irish constitutional Republic. History tells us that: 'the bond market began by facilitating government borrowing. In a crisis, however, it can end up dictating government policy' (Ferguson, 2009: 69). The Irish public and publics across Europe have come to understand that bond markets are deeply unforgiving.

Overwhelmingly, commentary on Ireland's woes has been sourced from the ranks of economics. Academic economists and economic journalists have taken centre stage. In the course of the Celtic Tiger years and its aftermath, economics became first our comfort blanket, and later our night terror. During this period of economisation, the concept of society and the attendant notion of a social sensibility were pushed to the sidelines. The dominance of the economistic perspective was in part facilitated by what Cullen (2008) and O'Riain (2010) have described as the financialisation of everyday life. The substitution of abstract financial instruments for money has been crucial to advanced market capitalism. Innovation in the sphere of high finance proceeded with little or no government controls, (Strange 1998; Dodd 2011). This has been evident in Ireland, for example, in the amount of news (print and electronic) devoted to business stories, the rise of the business correspondent/financial guru, the growth of specialist media devoted to financial issues, the explosion in the numbers of Irish people investing in stocks and shares during the boom years, the hyperbole surrounding the saving and splurging of SSIAs (Special Savings Investment Accounts, a scheme offered by the Government in 2000 to encourage savings in the population), and most consequentially, in the headlong rush to buy houses rather than homes. 'Build and they will come' was the ultimately illusory slogan of investors and developers during the height of the Irish property boom. A developer-driven agenda, aided by generous tax incentives for building in designated areas, ${ }^{2}$ resulted in tens of thousands of house completions and ancillary developments across the state. This construction tsunami presaged a fundamental shift in the way in which Irish people came to think about their homes. As Sparks and Duke (2010) have observed, traditionally the 'owned house-as-homestead' was 
understood, especially in rural areas, to be the core seat of family life and part of the bedrock of community membership. The home was where family name and place were entwined. In the boom years, however, the house became less a 'real' home and more an illusory signifier of status and wealth. The commercial value of houses appeared to trump the cultural value of homesteads, a trompe l'oeil that has proved costly both in financial and social terms for many Irish householders.

The 'boom to bust' narrative that framed recent experiences in Ireland has been consequential not just for the economy, but also for the polity and for the fabric of social life. John Cullen (2008) argues that changes in economic fortunes do not change people directly; they create situations and circumstances where an individual's sense of identity is open to compromise and challenge. Economies are cyclical and the economic fortunes of any region or nation change continuously. Economics assumes that these changes do things to people but neglects to think about what people can do in response to these changes. One of the challenges now faced is how to move from being at the mercy of processes of economisation to mastering those processes, and refashioning them in the interest of the public good.

\section{The drift toward privatisation and the decline of the public self}

Receiving a diagnosis of serious illness is a traumatic event in itself. In Ireland it is further exacerbated by the question which comes to many people's mind: would it be better to seek treatment privately? Will the private insurance (to which more than two million people contribute) mean quicker access to treatment? There is no evidence that individuals receive better care in the private health care system than in the public system (once the latter has been accessed). In fact, the opposite may well be the case, but the point is that the doubt is raised. There is a generalised questioning of the capacity of the public system to adequately deliver. It is this doubt - fanned by the media and critics of public provision - that has driven a corrosive wedge between the public and the private in contemporary society. Moreover, people are encouraged to believe that ability to pay - to purchase health treatment as a discerning rational actor rather than access it as a universal right of citizenship - will guarantee a better outcome.

Everywhere one looks public services are being diminished, materially in terms of their resourcing and symbolically in terms of the weight of critique that is levelled against them. It is not a peculiarly Irish problem. Rather it is the outcome of thirty years in which an agenda of 'private affluence and public squalor' (in the words of Tony Judt) has been advanced. Health providers, educators and public servants are the butt of broadsides from politicians, private sector cheerleaders and the media. Cawley's (2010) analysis of media framing of the public sector from 2008-10 is instructive in this regard. He demonstrates that media reporting configured the public sector as in an oppositional relationship to the 
private sector, with the public sector most commonly associated with 'cost', 'burden' and 'spending' whereas the private sector was mostly associated with 'investment' and 'wealth creation'. ${ }^{3}$

The Reithian ${ }^{4}$ principles underlying public service broadcasting have been diluted. To justify their existence and deliver audiences the national broadcaster dumbs down its schedule, celebrifies its content and turns increasingly toward the reality TV genre. New media may promise the possibility of a new frontier for the public sphere, but it is a public sphere that is circumscribed. In the wake of the Arab Spring of 2011, media analysts argued that the internet had become a major force for democratic renewal. Academics took a more nuanced view. Anderson suggested that the critical issue underpinning the story of the Arab Spring was not how activists used technology to share ideas and tactics but rather 'how and why these ambitions and techniques resonated in their various local contexts' (2011: 2). In other words, the role of technology in political mobilisation cannot easily be divorced from the local context. While Zhuo, Wellman and Yu (2011) concede that social media was implicated in mobilising and organising the revolt in Egypt, they also caution that social media's role should not be overestimated. Only 20 per cent of the Egyptian population had direct access to social media, though through a more old-fashioned two-step flow of communication, many more than that core of users could be contacted and mobilised. Hence, several governments tried temporarily to restrict or shut off the internet during the Arab Spring, and some are now seeking more permanent ways to limit its influence. ${ }^{5}$

Still Zhou et al. suggest that it was primarily strong ties that convinced friends and family to join demonstrations, while weak ties provided the network for information diffusion. This bears out Malcolm Gladwell's (2010) provocative claim that weak ties which are primarily favoured by social media networks do not a revolution make. Weak ties in themselves seldom lead to high-risk activism:

The internet makes it easier for activists to express themselves, and harder for that expression to have any impact. The instruments of social media are well suited to making the existing social order more efficient. They are not a natural enemy of the status quo.

Gladwell uses the historical case of the freedom rides in the 1960s to prove his point that strong ties are a sine qua non for the creation and maintenance of activism especially in the face of repressive opposition on the part of the state. Virtual diffusion networks should not be confused with real civically integrated publics. Technology has both the tendency to segregate and integrate civil publics. As Kumar and Makarova observe:

... mobile phones, iPods, portable laptop computers, all these allow us to carry our private worlds with us into the public spaces. We are cocooned from the environment of other people by this almost solipsistic technology. We might (we have all 
seen this) be walking side by side with a companion. And we might be talking. But we are not talking to each other, not conversing. We are holding separate conversations on our mobile phones with other people who are not here in bodily presence but in remote or virtual space ... (2008: 333)

Public intellectuals find it harder to connect with audiences in a culture which more readily values the spontaneous tweet over the reflective tome. Indeed, it is widely claimed that their role is in terminal decline, (Posner 2001; McLaughlin 2011). Public intellectuals historically have received cold comfort in Ireland, (Garvin 2012). As O'Dowd has observed in 'a society which traditionally placed a high value on conformity and cultural homogenization, the serial critic and dissenter runs the risk of marginalization' (2012: 81).

The idea of public service itself - whether a practical or intellectual enterprise - has been debased particularly within the political realm. Ireland has only recently ushered out a generation of politicians many of whom placed personal gain ahead of the public good. It is not surprising that the Irish public has moved from disenchantment to disengagement to disgust. In the battle to win our hearts and minds, it seems somewhat inevitable that it is products of reality TV programmes such as pop duo Jedward or singer Susan Boyle who enchant us rather than the leaders of the government or the opposition.

More worryingly, our public stock of knowledge is also diminishing. We are increasingly confronting functional knowledge deficits that challenge the democratic ideal of the well-informed citizen (Ungar 2008: 301). Many of us remain caught in what Ungar describes as a knowledge-ignorance paradox. Innumeracy and economic illiteracy are widely found in modern 'advanced' societies (2008: 309). Indeed functional knowledge deficits particularly in relation to financial accounting, are at least in part responsible for the current economic impasse. Moreover, political illiteracy more generally has fed the lurch to the right across Europe and also in the USA, where the success of the Tea Party is predicated upon an ingrained ignorance about the provenance of the US constitution. The underlying process of economisation that took hold over the last decade enabled the commodification and privatisation of more and more areas of life, and the systematic devaluation of 'the public' broadly defined. It presents us with a huge challenge: how do we re-socialise everyday life? How can we meaningfully move beyond the debasement of the public? What means do we have at our disposal to re-appropriate and re-animate 'publicness' among the body politic? Is it possible to reconfigure the public-private relationship? And where do we start?

I propose to focus on one aspect of the public realm broadly defined - the public space of the city that in theory is open and free to all but whose usage has over time become increasingly contingent and conditional. Why focus on the city? While public space itself has been in retreat it is possible to identify real and potential nodes of resistance in urban activities and practices, which afford the opportunity for public revitalisation. According to Kumar and Makarova, 
while the concept of separate spheres (public versus private) is developed within social and political theory, it has been analysts of the space of the city that have demonstrated the most sensitivity to the interaction or interpenetration of public and private in the built environment:

It is as if the very materiality of urban space forces upon the observer the awareness of the permeability of the public-private distinction, and of the way public and private sustain and support each other. (Kumar and Makarova 2008: 329)

The city then offers a window through which we can re-imagine some of the binary oppositions discussed above. In the remainder of this paper I will focus on an exploration of public space in the city, the challenges which it faces and the emergent 'spaces of potential' that can generate civil integration which affords opportunities to re-socialise everyday life.

\section{Public space: a space of civility and sociability}

While there is a proprietorial or commercial interest in private space, public space is commonly shared and designed for open use by the community. ${ }^{6}$ Citing the Greek agora and the Roman forum, Mitchell asserts that public space occupies an important ideological position in democratic societies (1995: 116). Definitions vary but most emphasise either the notion of civility or sociability. In her classic work on the urban public realm, Lyn Lofland (1973) defines public space as those areas of a city to which all persons enjoy legal access. They belong to no one and therefore to everyone. 'Public space is traditionally differentiated from private space in terms of the rules of access, the source and nature of control over entry to a space, individual and collective behaviour sanctioned in specific spaces, and rules of use' (Low and Smith 2007: 4). Public space 'is accessible to everyone who conforms somewhat to the very generally expected patterns of action' (Blokland 2003: 91). Low barriers to entry are the key to public spaces, which should be cost free, with no requirements of users and certainly no exclusion on the grounds of gender, race and so on. According to Richard Sennett (2005) the public space of a city enables encounters between strangers in its streets, squares, parks and so on. Public space demands a level of civility from its users in order for the city to work. Dines and Cattel (2006) describe public spaces as 'sites of sociability and face-to-face interaction, and at the same time their quality is commonly perceived to be a measure of the quality of urban life' (cited in Lownsbrough and Beunderman 2007).

The landscapes of public space are both physically and socially constructed and imbued with a multitude of meanings. Jacobs (1961) observed networks of social relationships in the city's public realm as actors meandered through and across each other's lives each performing their own individual part in an intricate, aggregated whole. Public space, far from being marginal space in the city, can therefore be defined by its centrality to the city's lifeworld. Ideally, 
individuals and communities create and sustain civil interfaces in this lifeworld, where barriers are dismantled, knowledge is exchanged, stereotypes are challenged, empathies are generated and where people get on with the business of simply getting on with their lives. Public spaces must be capable of generating what Vertovec calls civil integration:

the acquisition and routinization of everyday practices for getting on with others in the inherently fleeting encounters that comprise city life. (2003: 4)

Cities offer most potential for generating civil integration because historically they have placed a premium on the provision of public spaces - accessible to all. However, a feature of late modernity to which I have already alluded is the privatisation of social life and the concomitant individualisation of formerly social practices, resulting in the decline of the public realm broadly defined. This has occurred against a backdrop where the commitment to the concept of the public and public goods in general has been severely tested as outlined above.

As the traditional role and fiscal capacity of the state has shrunk, the role of the private has increased (Banerjee 2001). The recent history of the Irish city exemplifies these trends. The growth of consumerism evidenced in the rise of 'Yummy Drummy' culture ${ }^{7}$ (see Cunningham 2008); the drift toward commodification notable in city branding campaigns (see Corcoran 2005), and the focus on the entrepreneurial city - a city that can do business - are hallmarks of creeping privatisation. Secondly, Banerjee notes that the restructuring of the global economy has implications for the local level. The opposition between local and global interests frequently results in the public interest being made subservient to the needs of global capital, as for instance, in planning battles over the vernacular of the city (see Corcoran 2000). Finally, while new information technologies may expand the range and remit of individual communication and interaction they do so potentially at the expense of traditional notions of locality, place, community and belonging.

In a similar vein, Ray Oldenburg expresses concern about the sustainability of third places, neutral places (neither home or workplaces) in which the attendees are neither 'hosts' nor 'guests' and where people should feel relaxed and at ease. The Irish pub has historically occupied the role of a third place: a communal place, with a convivial atmosphere, where people got to know and like one another (Scarbrough 2008). Oldenburg highlights the importance of such informal places for maintaining civil society and democratic engagement. But, third places are under threat, he argues, from the prevalence of television, suburban sprawl and commercialisation. Third places are declining and are being replaced by non-places where individuals (rather than social citizens) relate to one another in purely utilitarian terms (as customers, shoppers, clients, patients, etc.). Such non-places are more likely to promote civil dis-affiliation rather than civil integration. 


\section{Spaces of potential}

In the final section of this paper I want to argue for an imaginative approach in thinking about how to constitute or re-constitute the urban public realm. Here I am following Lownsbrough and Buenderman (2007) who set out to identify old, renewed and emergent public spaces in cities and neighbourhoods. These spaces may be formal and informal, public and semi-public, deliberate or spontaneous. Their analysis identifies eight main types of these 'spaces of potential' - productive, exchange, service provision, activity, democratic/participative, staged, in-between and virtual. Even a cursory exploration of everyday Irish life demonstrates the presence of such diverse spaces of potential to one degree or another. These are spaces that allow for and encourage civil integration. Productive spaces such as allotments and community gardens have been flourishing in and around cities and their hinterlands in recent years. We will return to these spaces later. Farmers' markets, which have become ubiquitous in city locations, suburban outposts and small towns, constitute a space of exchange. Libraries have been quietly reinventing themselves for the twenty-first century and constitute an outstanding example of service provision in the public realm. ${ }^{8}$ There are any number of examples of activity-based spaces of potential upon which we can draw: city marathons, the annual Liffey swim or the Forty Foot swimming point in Sandycove, Co. Dublin immediately come to mind. ${ }^{9}$ These are examples of habitual events that are open to all, have low barriers to entry and provide opportunities for fleeting encounters in the public arena, the effect of which is to reinforce conviviality in the city.

Democratic/participative spaces encompass initiatives as diverse as Claiming our Future, a loose federation of civil society groups that have come together to explore how best to cooperate and coordinate endeavours for a more equal, inclusive and sustainable Ireland (www.claimingourfuture.ie), and the Men's Shed project in Co. Meath which provides a meeting place for older men to come together and enjoy activities such as woodwork, metalwork, photography, card playing, darts and bowls (Healy 2010). Dun Laoghaire has been at the forefront in staged 'spaces of potential' for a number of years hosting the Annual Festival of World Cultures and the Mountains to the Sea book festival, both of which draw large crowds to the locality. In-between spaces of potential include pop-up events that arrest the quotidian, temporary art installations that critique Celtic Tiger excess ${ }^{10}$ and participatory arts practice. Cross-community organising in divided cities such as Belfast seeks to make constructive use of in-between or 'disputed' spaces. Finally, virtual 'spaces of potential' operate through computer-mediated communication. In just one week towards the end of 2010, the Rubberbandits"11 satirical takes on Celtic Tiger bling and blustering politicians in Limerick plugged into an audience of millions and created a national talking point. 
Although the examples I have given above are discrete, they should not be interpreted in a narrowly spatial sense. In practice many 'spaces of potential' will be characterised by elements that cut across more than one definition or activity. What these spaces have in common is the central importance of trust and confidence from users in creating and relating to public space. They demonstrate the possibility of appropriating spaces in and around the city for the public good. The elements of contemporary public space according to Lownsbrough and Buenderman must include: multi-use, accessibility, legibility, clarity about the boundaries between public and private; local relevance, adaptability to people's diverse and changing needs and desires; open-ended, safe and welcoming. A key challenge is to think more radically and imaginatively about where such places have been, where they are and where they might be in the city of the future.

I suggest that a key 'space of potential' in the context of urban centres such as Dublin is the allotment and community garden, complementary versions of urban agriculture. These have the potential to reinvigorate sites that are unused or underutilised, to make brownfield sites green, to create sustainable models of growth and development, and to revive the public realm of the city. Interest in urban agriculture has predominantly focused on its contribution to sustainability in cities of the developing world (Mougeot 2005, 2006). There is however a long European history of allotment gardening borne out of citizens' efforts to bring nature into the city (Meller 2005). A number of factors, including the rezoning of land for residential and commercial use and the growing privatisation of everyday life, led to a decline in allotment gardens in the second half of the twentieth century. Nevertheless, the idea of urban agriculture continues to be part of the fabric of European urban life.

Allotment gardening in Ireland has undergone a steady revival in recent years. ${ }^{12}$ In Dublin, the demand for allotments currently far outstrips supply. Allotment associations and food grower organisations are proliferating and there are many private allotment sites opening around the country. In the Dublin regional area, the four city councils among them provide just over 1,100 allotments. These are supplemented by a significant number of privately provisioned allotments in the County of Dublin and the adjacent counties of Meath, Wicklow and Kildare. Whether publicly or privately leased, allotments are designated sites for the cultivation of fruit and vegetables for domestic consumption. They are embedded in local landscapes and benefit from local resources (such as soil quality). Moreover, they enable an integrated form of production, consumption and exchange, that is predicated on the sharing of local knowledge and skills. A key feature of the allotment sites is their facilitation of opportunities for social mixing, social levelling and interaction with unknown others, as the following excerpts from interviews with allotment holders illustrate:

That is the huge potential of allotments, the sense of bringing people together. I really feel that. I have seen that countless times. Out there, there are no boundaries 
or barriers, it is a great social mixing place. Now more people on neighbouring plots might get to know each other because there are no walls or fences like there are with gardens. Every plot almost merges into the next ... (Interviewee MF, August 2009)

you're up there in your working clothes, there's no symbols of wealth as such. There's no suits, you know there's no people dressed in their good clobber. You're in there with your spade and your veg and it's kind of ...it's a neutralising environment where you wouldn't feel threatened by talking to another person. (Interviewee FN2, August 2009)

Allotments facilitate the striking up of convivial interactions between plotholders, they are places where strangers seem less strange. There is a shared commitment to cultivation which is predicated on an incipient shared identity and co-operative relations. Yet, crucially, intimacy is not a requirement. Allotments respect the private self and do not require strangers to become friends. They simply enable what Ash Amin has described as 'an occupancy of shared turf' (Amin 2010). In this sense, the allotment allows for the interpenetration of public and private; as spaces they enable both publicness and privacy:

When I'm coming for four hours I'll always bring me flask and if someone was around I would say do you want a cup of tea, they might take it and they mightened take it (FN1, September 2009)

... there are a lot of people up there in the allotments but when you are on your allotment and you're working you tend to go into a private space in our own mind which in that way it is private, you know ... People don't necessarily bother you up there and yet conversation can start up with people quite easily ... I got to know a good few people, it was a kind of unconditional thing. You didn't have to communicate if you didn't want to ... (FN2, August 2009)

The testimonies gathered from allotment gardeners is suggestive that for them allotments constitute liminal spaces or 'a space of potential' wherein they move easily between engaging in public activity and civil integration practices, while at the same time safeguarding the space as a semi-private realm. Following Kumar and Makarova (2008) allotments are suggestive of the permeability of the public-private distinction, demonstrating how public and private dimensions sustain and support each other. I argue that the allotment and the community garden have the potential to animate the urban public realm, re-appropriating the 'public' in cities at a time when wider forces are undermining access to and usage of public space. They are both spaces for inscribing individual identity and for private retreat, as well as arenas for chance encounters that may become habitual over time. They are increasingly diverse in terms of the age, ethnicity and gender profile and they encourage the development of cross-cutting networks and relationships. They create, therefore, a myriad of possibilities for civil integration in the context of the diverse city in the twenty-first century. 


\section{Conclusion}

This paper has moved from a discussion of the vagaries of the global financial system to an exploration of local resilience exemplified in a case study of urban agricultural initiatives. My intention has been to demonstrate that even in the face of forces that threaten the viability of 'the public' humans demonstrate the capacity to reanimate old 'spaces of potential' and generate new ones adapted to the conditions of the twenty-first century. I argued that the two processes of economisation and privatisation have weakened (but not destroyed) our notions of the social self and the public self. I noted that the city historically has been a site of 'publicness' but that here too, the public is in retreat. The paper then moved toward an examination of how the notion of publicness and public good could, somehow, be re-appropriated within the context of the contemporary city and its environs. Kaul, Grunberg and Stern (1999) define public goods as outside the marketplace and as accruing benefits arising from their non-rivalry in consumption and non-excludability. Secondly, their benefits are universal in terms of being accessible to all population groups, and they do not foreclose options for future generations. I have attempted to show how there are a myriad of 'spaces of potential'- manifest and latent - alive and well in the city. These can be seen as constituting public goods. Urban agricultural initiatives such as allotments constitute such a public good - in terms of the resource that is offered (publicly provided and serviced land), shared meaning (production and consumption largely outside the market) and behavioural expectations (working alone or together with others diligently benefits all and contributes to the common good). Allotments cannot sustain free riders indefinitely, because a plot holder who does not adequately tend his or her plot, damages the collective good.

Allotments are liminal spaces in that their location has varied over the course of the last century, as land has been leased for, and then released from, cultivation. They come into being only when the commercial or more utilitarian functions of a land mass are on hold. Despite broad support for the idea of allotments there has been considerable resistance down through the years to making them a permanent feature of the urban landscape. Maybe it is time to change that way of thinking. Allotments make economic sense, environmental sense but also social sense. They are the perfect antidote to gated individualism.

Lownsbrough and Beunderman (2007) argue that to really understand public spaces we must be guided by what people themselves make of public spaces, in their everyday experiences and spatial practices. It seems to me that the local authority-provided allotments in the city of Dublin constitute 'spaces of potential'. On the one hand, the barriers to entry are relatively low in terms of the fees charged, and they are, in theory, open to all. On the other hand, they have very low public visibility, and are in the main, car dependent. They are both spaces 
for inscribing individual identity and for private retreat, as well as arenas for chance encounters that may become habitual over time. They are increasingly diverse in terms of the age and gender profile and they encourage the development of cross-cutting networks and relationships. People on allotment sites may move easily between private, parochial and public realm. Allotments constitute a significant intervention in urban space, highlighting as they do the liminality, fluidity and shifting quality of the boundaries associated with that space.

How the city of Dublin - and indeed other cities around Ireland - will evolve in the years to come will be contingent on the core values and principles that underpin citizens' vision for the city. Allotments, community gardens, participatory arts, public libraries, civil society mobilisations and so on will have to move from the margins to the mainstream if we are to make our cities and communities more liveable, more convivial and more sustainable into the future. Spaces of potential can help to make a space for 'a politics of the commons' because they are rooted in the repertoires of urban citizens who belong to multiple geographies of affiliations (Amin 2010). They may help us to construct a new narrative of the city that moves beyond the idea of a future of catastrophe and towards a politics of hope. But, as Amin points out, the achievement of the public and a politics of the commons requires promotional work - to foment a collective urban infrastructure and a collective urban consciousness. Such a consciousness developed through public activism and social engagement can challenge the economistic lens to accommodate alternative perspectives and models of citizenship. Only then can we hope to generate a re-socialised version of Irish citizenship and Irish sovereignty.

\section{Notes}

1 A version of this paper was presented at the ISSP Conference 'The Social Sciences in an Age of Uncertainty: Knowledge, Innovation, Society and Space', University of Limerick, 3 December 2010. I would like to thank two anonymous referees and the editors of the Irish Journal of Sociology for their comments.

2 The impetus for urban regeneration in Ireland was provided in the first instance by the Urban Renewal Act (1986) which made available a generous package of tax-based incentives to developers, investors and homeowners. The urban renewal scheme was designed to promote private investment in the built environment of designated inner-city areas either through refurbishment of existing buildings or through new developments. Rent allowances and rate remissions made these incentives highly attractive to commercial developers.

3 Cawley's research is based on a substantial sample of articles from the main Irish daily and Sunday newspapers: The Irish Times, Irish Independent, Irish Examiner, Evening Herald, The Sunday Independent, The Sunday Tribune, and The Sunday Business Post. The study highlights recurrent words that were used to encode meanings and preferred interpretations in media articles: e.g. bloated, privileged, pampered, cosseted and wasteful for the public service; vibrant, innovative and driven for the private sector. Framing analysis of the sample also suggests an 'othering' of the public sector from the 'national interest' and 'public interest' through the 
use of recurrent phases such as 'holding "us" to ransom' and failing to 'share the pain' with a private sector that often was described as 'taking the pain' and 'shouldering the burden'.

4 John Reith was the first Director-General of the BBC. The term 'Reithianism' describes certain principles of broadcasting to which Reith subscribed and includes an equal consideration of all viewpoints, probity, universality and a commitment to public service. The public service model is distinguished from the free market approach to broadcasting, which tends to be primarily profit driven and market oriented.

5 See 'The Arab Spring's online backlash', The Economist, 29 March 2012.

6 The idea of a single public itself, however, is difficult to sustain (Bridge and Watson 2000). If public space is defined as space to 'which normally people have unrestricted access and right of way' (Fyfe and Bannister 1996) it is difficult to make the argument that any space has ever held such a status, (Atkinson 2003). Public spaces are subject to limitations in relation to usage - certain types of behaviour deemed unlawful or 'out of place' are proscribed. Indeed, public space is ruled by both implicit and explicit rules and expectations regarding types of appropriate behaviour. The 'publicness' of public space is a contested issue.

The space of the public park, for instance, can produce collisions and intersections between private, parochial and public realms. Lofland argues that small pieces of private space which she refers to as 'bubbles' may intrude into public space (1998: 12). Portions of parks can be reserved for concerts, markets, skateboarding, etc. creating boundaries or exclusions. For Lofland the private bubble of a space allows for an appropriation of public space resulting in a degree of privatisation. The boundaries between what constitutes public and private become more fluid and permeable.

7 Yummy Mummies is a term coined to describe middle-class mothers who do not work outside the home and whose leisure time is spent socialising with other mothers of their ilk. The term Yummy Drummy was coined to describe Yummy Mummies and their offspring who enjoy the consumption experience of Dundrum Town Centre in South Dublin, one of Europe's biggest shopping malls.

8 According to a senior Garda officer with a diversity and community relations remit, the most integrated space in the city of Dublin is Blanchardstown Public Library (personal communication, September 2010).

9 The Liffey Swim, now in its ninety-first year, is held annually in Dublin's main river, the Liffey. It is one of Ireland's most famous traditional sporting events, organised by Swim Ireland and managed by volunteers. Many levels and ages of swimmers compete in the race, but entrants must be a member of a swimming club and be able to swim a mile.

The Forty Foot is a promontory on the southern tip of Dublin Bay at Sandycove, in County Dublin. It has been a popular all year round bathing point for people for 250 years. Originally a gentlemen's only bathing place, it has since the 1970 s been open to women and children as well. The gentlemen's swimming club still exists and is open to both sexes, encouraging its members to make voluntary contributions to the upkeep of the area.

10 Andrew Duggan's work with Cindy Cummings is a case in point. They developed 9.8MPS, a documentation of an installation, performance and outdoor projection, a work commissioned for the Eigse Carlow Arts Festival. The work was located in a two-storey semi-detached house in a 'pre-lived' vacant housing estate in the very popular, ubiquitous early twenty-first century Irish Property 'Developist' Style. 
11 The Rubberbandits are the award-winning hip-hop comedy duo of Blindboy Boat Club and Mr. Chrome from Limerick. Primarily a satirical stage and television act, they have performed throughout Ireland, the UK and USA with shows at events such as Electric Picnic, Oxygen and the Bulmers International Comedy Festival. The Rubberbandits have won awards for both their music and comedy.

12 The information provided here is drawn from preliminary data collected in public and privately provided allotment gardens in the Greater Dublin area in summer 2009 and spring 2011. Visual evidence of allotment gardening was collated and approximately thirty interviews were conducted with allotment gardeners, advocates and city council officials in the region. Data was collected by M. Corcoran, M. Benson, J. Hayes and P. Kettle. The research was supported by the NUI Maynooth Spur programme, and will be developed further in the context of COST Action TD1106 Urban Agriculture Europe.

\section{References}

Anderson, Lisa 2011. 'Demystifying the Arab Spring', Foreign Affairs 90(2).

Amin, Ash 2010. 'Cities and the ethnic of care among strangers', keynote address to One City, One People Conference, Dublin City Council, 24 September.

Atkinson, R. 2003. 'Domestication by cappuccino or a revenge on urban space? Control and empowerment in the management of public spaces', Urban Studies, 40(9): $1211-45$.

Banerjee, Tribid 2001. 'The future of public space. Beyond invented streets and reinvented places', Journal of the American Planning Association 67(1): 9-24.

Blokland, T. 2003. Urban Bonds. Cambridge: Polity Press.

Bridge, G.H. and S. Watson 2000. 'City publics', pp. 369-79 in G. Bridge and S. Watson (eds), A Companion to the City. Oxford: Blackwell.

Cawley, Anthony 2010. 'Sharing the pain or shouldering the burden? Media framing of the public sector and the private sector during the economic crisis, 2008-2010', paper presented at ISSP Conference, 2 December, University of Limerick.

Corcoran, M.P. 2000. 'Mall City', pp. 91-103 in E. Slater and M. Peillon (eds), Memories of the Present. Dublin: Institute of Public Administration.

Corcoran, M.P. 2005. 'The spectacle of the spire: reinventing O'Connell Street in Dublin', Sociologie et Societes, Special Issue on 'Le Spectacle Des Villes' XXXVII(1) Spring: 69-86.

Cullen, John 2008. 'The Pope's Children and the economisation of social change', pp. 19-27 in M. Corcoran and P. Share (eds), Belongings: Shaping Identity in Modern Ireland. Dublin: Institute of Public Administration.

Cunningham, Tony 2008. 'Jesus in Dundrum: Between God and Mammon', pp. 23143 in M.P. Corcoran and P. Share (eds), Belongings: Shaping Identity in Modern Ireland. Dublin: Institute of Public Administration.

Dines, N. and V. Cattel 2006. Public Spaces, Social Realities and Well-being in East London. Bristol: Policy Press.

Dodd, N. 2011. 'Strange money: risk, finance and socialized debt', British Journal of Sociology 62(1): 175-94.

Ferguson, Niall 2009. The Ascent of Money: A Financial History of the World. London: Penguin.

Fyfe, N.R. and J. Bannister 1996. 'City watching: closed circuit television surveillance in public space’, Area 28(1): 37-46.

Garvin, Tom 2012. 'The bleak future of the Irish university', Irish Times, 1 May. 
Gladwell, Malcolm 2010. 'Small change: why the revolution will not be tweeted', The New Yorker, 4 October.

Healy, Alison 2010. 'Meath “men's shed” project provides new outlet', Irish Times, 15 November.

Jacobs, Jane 1961. The Death and Life of Great American Cities. New York: Random House.

Judt, Tony 2010. Ill Fares the Land. London: Penguin.

Kaul, Inge, Isabelle Grunberg and Marc A. Stern (eds) 1999. Global Public Goods: International Cooperation in the 21st Century. New York: Oxford University Press for United Nations Development Programme.

Kumar, Krishan and Ekaterina Makarova 2008. 'The portable home: the domestication of public space', Sociological Theory 26(4) December: 324-44.

Lofland, Lyn H. 1973. A World of Strangers: Order and Action in Urban Public Space. New York: Basic Books.

Lofland, Lyn H. 1998. The Public Realm: Exploring the City's Quintessential Social Territory. Hawthorne, NY: Aldine de Gruyter.

Low, S. and N. Smith (eds) 2007. The Politics of Public Space. London: Routledge.

Lownsbrough, H. and J. Beunderman 2007. Equally Spaced? Public Space and Interaction Between Diverse Communities. London: Demos.

McLaughlin, N. 2011. 'Public intellectuals and public academics: rhetoric and realities', paper presented at Department of Sociology, UCD, 29 September.

Meller, H. 2005. 'Citizens in pursuit of nature: gardens, allotments and private spaces in European cities 1850-2000', in D. Schott et al. (eds), Resources of the City: Contribution to an Environmental History of Modern Europe. Aldershot: Ashgate.

Mitchell, Don 1995. 'The end of public space? People's park, definitions of the public, and democracy', Annals of the Association of American Geographers 85(1): 108-33.

Mougeot, Luc J.A. 2005. Agropolis: The Social Political and Environmental Dimensions Of Urban Agriculture. London and Sterling, VA: Earthscan/IDRC.

Mougeot, Luc J.A. 2006. In Focus: Growing Better Cities. Urban Agriculture for Sustainable Development. Canada: IDRC.

O'Dowd, Liam 2012. 'Public intellectuals and the 'crisis': accountability, democracy and market fundamentalism', pp. 77-102 in M.P. Corcoran and K. Lalor (eds), Reflections on Crisis: The Role of the Public Intellectual. Dublin: Royal Irish Academy.

Oldenburg, R. 1989. The Great Good Place. New York: Paragon House.

O'Riain, Sean 2010. 'Snatching defeat from the jaws of victory: Ireland rediscovers crisis', pp. 21-33 in M.P.Corcoran and P. Share (eds), Ireland of the Illusions. Dublin: IPA.

Palley, Thomas I. 2004. 'From Keynesianism to Neo-liberalism: shifting paradigms of economics', www.fpif.org/articles/from_keynesianism_to_neoliberalism_shifting_ paradigms in economics, accessed 25 April_2012.

Posner, R.A. 2001. Public Intellectuals: A Study of Decline. Cambridge, MA: Harvard University Press.

Scarbrough, Gwen 2008. 'New places, non-places and the changing landscape of the Irish pub', pp. 57-70 in M.P. Corcoran and P. Share (eds), Belongings: Shaping Identity in Modern Ireland. Dublin: Institute of Public Administration.

Sennett, Richard 2005. 'Civility', Urban Age Bulletin 1, Summer.

Simmel, Georg [1907] 1978. The Philosophy of Money, edited by Tom Bottomore and David Frisby. London: Routledge and Kegan Paul.

Sparks, C. and K. Dukes. 2010 “"All that is solid melts into air": empty hopes and empty houses in Leitrim', pp. 103-15 in P. Share and M.P. Corcoran (eds), Ireland of the Illusions. Dublin: IPA. 
Strange, Susan 1998. Mad Money. Manchester: Manchester University Press.

Ungar, S. 2008. 'Ignorance as an under-identified social problem', British Journal of Sociology 59(2): 301-26.

Vertovec, S. 2007. New Complexities of Cohesion in Britain. London: Commission of Integration and Cohesion, p. 4.

Zhou, X., B. Wellman and J. Yu 2011. 'Egypt: the first internet revolt?', Peace Magazine, July-Sept: 6-10. 